of these researches are contained in "Geography in the Middle Ages" (Methuen, 1938), in a memoir accompanying the Royal Geographical Society's reproduction of "The Catalan World Map of the R. Biblioteca Estense at Modena" (1934), and in a critical edition of Pacheco's "Esmeraldo de Situ Orbis", published by the Hakluyt Society (1937). On the human side he has made a number of studies of marginal environments and economies, notably of the Berbers of the Algerian Atlas (Geog. J., 1941), and shortly before the War he wrote a popular introduction to the subject called "The World's Open Spaces" for Nelson's Discussion Series. The preoccupations of the past five years may be held to explain the temporary diversion of his interests as revealed in his most recent publications, namely, "The Shepherd of Banbury's Rules for Telling the Weather" (University of Reading, 1941) and "The Weather" (with Raymond Bush) published by Penguin Books in 1943. Mr. Kimble hopes to take up his new appointment in January 1945.

\section{Pulkovo Observatory Library}

AxthоUGH information had been received that the most valuable of the instruments had been removed from the Pulkovo Observatory before it was shelled and bombed by the Germans, there had been no news about its valuable library, which contained many rare treasures, including the manuscripts of Kepler. It is now learned from the Moscow News that the library had remained in the building, stored away in the basements. After the Observatory had been shelled for three weeks, it was decided to save the library at any cost. In the middle of October 1941, under incessant German artillery fire, the removal of the library was undertaken by the employees of the Leningrad Museums and Park Administration. Truck after truck pulled up to Pulkovo until all the books had been removed. The Observatory is now a mass of ruins, but the Academy of Sciences of the U.S.S.R. has been instructed by the Government to draw up and present by November 1 a project for the rehabilitation of the Observatory.

\section{Illuminating Engineering Society}

ThE presidential address delivered by Mr. E. Stroud at the opening meeting of the Illuminating Engineering Society on October 10 took the form of a survey of the Society's activities and its future. The Society was formed by Mr. Leon Gaster in 1909 and its first president was Prof. Silvanus P. Thompson. At that time there was little information in regard to lighting practice, and the instruments available for the measurement of illumination were few and cumbersome. Much original work was done by Mr. A. P. Trotter and other early pioneers to deal with the lighting of schools and libraries and other subjects. The setting up of the Home Office Committee on Factory Lighting in 1913 was an important landmark. During the War of 1914-18 members of the Society did useful work on the measurement of the candle-power of flares and the brightness of radium compounds for coating gunsights, etc., and the year 1915 saw the issue of the first of the series of reports on factory lighting issued by the Departmental Committee. During the first twenty years the foundations of the Society were laid. The floodlighting of London buildings, which accompanied the holding of the International Illumination Congress in London in
1931, did much to direct attention to its work. Efforts were made to create interest in the provinces, where the first centre, in Manchester, was formed in 1932.

From 1934 onwards there ensued a period of development. The membership, at this time about 450 , advanced to 850 at the commencement of the present War, and has now reached more than 1,600 -nearly a fourfold increase during these ten years. Several ambitions of the Society have since been realized, such as the formation of the nucleus of a library, the issue of Transactions and the establishment of a class of fellowship. This present growth of membership has been mainly due to the development of centres, now ten in number, with which, and with five supplementary groups, there are associated more than a thousand members. The growing recognition of the importance of good lighting is illustrated by the official recognition given to the I.E.S. Code of values of illumination. The inclusion of lighting in the Factory Act of 1937 makes good an omission stressed by Prof. Silvanus Thompson in his inaugural address thirty-five years ago. During the present War the Society has devoted much attention to A.R.P. lighting problems. A series of "Lighting Reconstruction" pamphlets has also been issued. There are various plans in preparation, such as those relating to the education of lighting engineers. In years to come there should be great opportunities for lighting. Closer links should be established with the sister societies in the United States and the Dominions, and international contact should be revived.

\section{Dried Plasma Sheets for Burns and War Wounds}

"IT has often been said," remarks Lieut.-Colonel B. Pollock, U.S.N.R. (U.S. Naval Bull., 42, 1171 ; 1944), "that this is a burn war." The incidence of burns has greatly increased, and there is urgent need of an ideal coagulum for them. Such a coagulum should be durable, non-contractile, indefinitely pliable, non-toxic, non-irritant, resistant to trauma, bactericidal, painless, not unsightly, and it should contain fibrin and not be costly to make. Dried plasma sheets apparently come closer, he thinks, to these requirements than any other coagulum yet introduced. Dried plasma dissolved in water and dried in a hot oven gives a transparent, slightly elastic, adherent coagulum, and the addition of sulphanilamide or sulphathiazole increases its bactericidal effect. These substances are slowly liberated as the fibrin is used up, and they thus keep the wound clean.

The sheets are made in a Petri dish to a size of $4 \mathrm{in}$. in diameter. 20 c.c. of sterile water is put in the Petri dish and 1.5-2 gm. of dried plasma added. After this has dissolved $0.2 \mathrm{gm}$. of sulphanilamide powder is added. This is then dried in an oven at $140^{\circ} \mathrm{C}$. until a sheet is formed. This requires 15-20 minutes. After cooling, the sheet should be applied directly to the burn. Sheets can be quickly made by heating the preparation over a Bunsen burner until the sheet separates itself in less than five minutes. The addition of more or less water or plasma thickens or thins the sheet. Its transparency in. creases or decreases according to the amount of sulphanilamide added. If the preparation is dried for only ten minutes, it forms a paste which is also useful. The sheets tend to curl at the edges as skin does, but this can be overcome by moistening them with water before application. They adhere to a 